\title{
Giant gluteal lipoblastoma associated with hepatic haemangioma and bilateral nephromegaly
}

\author{
Ramnik V Patel, ${ }^{1,2}$ Augusto Zani, $^{3}$ Christina Panteli, ${ }^{3}$ Agostino Pierro ${ }^{4}$
}

${ }^{1}$ Department of Paediatric Urology, University College London Hospitals NHS Foundation Trust, London, UK ${ }^{2}$ Department of Paediatric Urology, Great Ormond Street Children Hospital NHS Trust, London, UK

${ }^{3}$ Department of Paediatric Surgery, GOSH, London, UK ${ }^{4}$ Department of Paediatric Surgery, GOSH and ICH, London, UK

\section{Correspondence to} Dr Ramnik V Patel, ramnik@doctors.org.uk

Accepted 26 April 2014

\section{DESCRIPTION}

An 11-month-old girl adopted from Guatemala was referred to us with a painless static massive swelling in the right buttock of 6 months duration. It was soft, mobile, lobulated and measured $6 \times 8 \mathrm{~cm}$. Ultrasound demonstrated a heterogeneous echogenic mass with a little Doppler flow within it. There was a small focal hypervascular lesion in the right lobe of the liver suggestive of a haemangioma. Both the kidneys were enlarged but normal. CT scan confirmed hepatic haemangioma and bilateral nephromegaly (figure 1A). It showed a large soft tissue mass of background fatty attenuation with abundant strands of enhancing soft tissue in the right gluteal region suggesting lipoblastoma (figures 1B-D). An MRI scan showed a welldefined predominately fatty signal of diameter $7 \mathrm{~cm}$ in the right gluteal muscles and confirmed hepatic haemangioma and bilateral nephromegaly. Biopsy confirmed lipoblastoma. She underwent total excision of lipoblastoma uneventfully. Histology showed lobulated architecture, with lobules of lipocytes and lipoblasts separated by prominent fibrovascular septae suggestive of lipoblastoma. She has been followed with serial ultrasound scans and the hepatic haemangioma slowly regressed and spontaneously resolved at 21 months, nephromegaly resolved to 50th centile at the age of 4 years and there is no tumour recurrence at 6 years follow-up. Lipoblastoma is a rare benign lipomatous tumour arising from embryonic white fat and encountered almost exclusively in infants and young children. ${ }^{1}$ Surgical excision is the treatment of choice but spontaneous resolution has been reported. ${ }^{2}$ In infancy and early childhood, the identification of a tumour composed mostly of fat should suggest the diagnosis of lipoblastoma or lipoblastomatosis. ${ }^{3}$ The coincidence of nephromegaly and liver haemangioendotheliomas has been reported in Beckwith-Wiedemann syndrome and other associated syndromes. ${ }^{4}{ }^{5}$ Nephromegaly means enlargement of kidneys which could be unilateral or bilateral and congenital or acquired. Congenital bilateral nephromegaly in association with live haemangioma and lipoblastoma may represent a variant of Beckwith-Wiedemann syndrome. It may represent nephroblastomatosis or it may regress as the patient grows older. In isolated nephromegaly, it may increase the risk of renal scarring if associated with vesicoureteral reflux. ${ }^{6}$
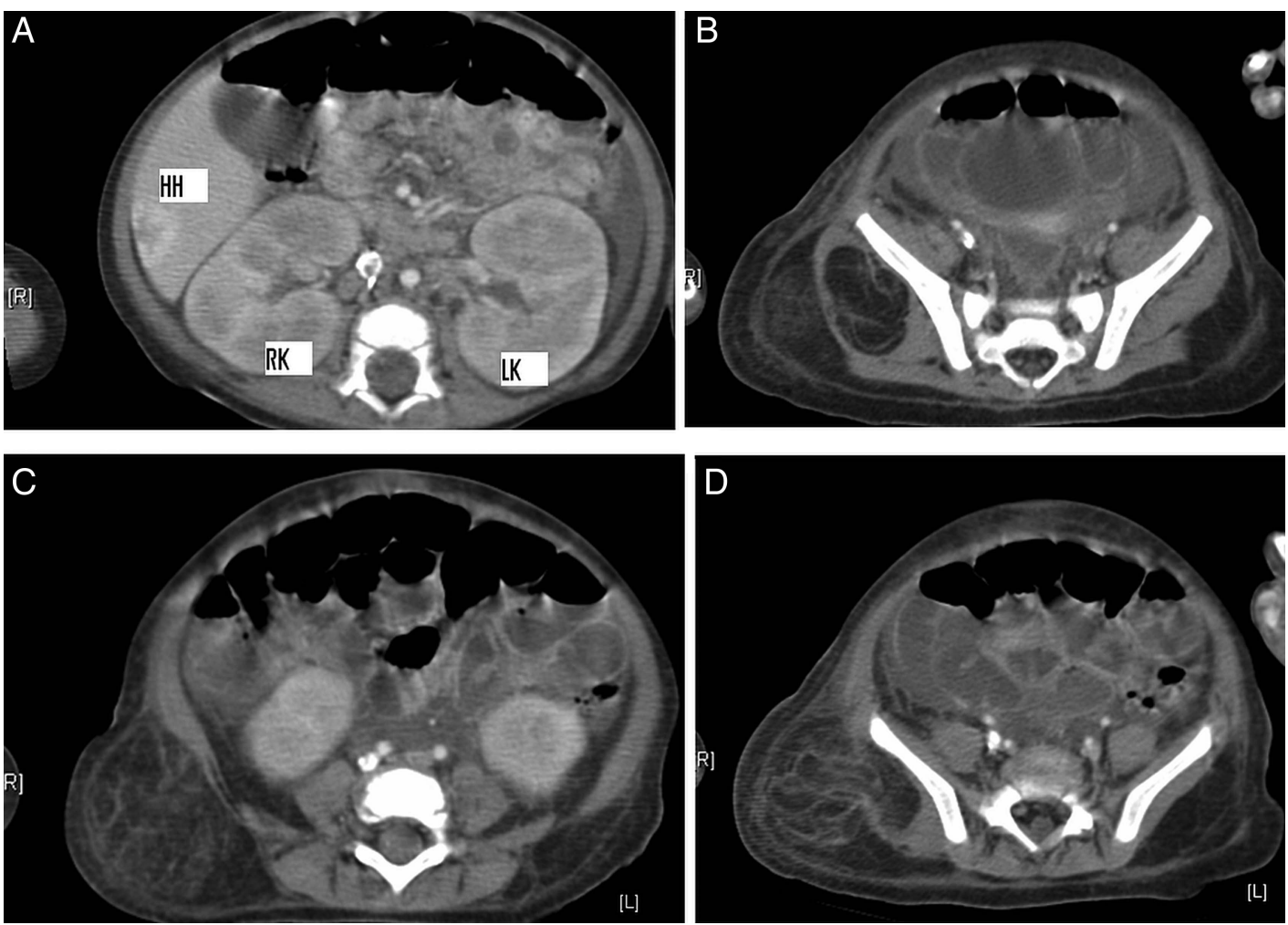

Figure 1 CT scan showing (A) hepatic haemangioma and bilateral nephromegaly (RK, LK), (B-D)—top, middle and bottom cuts of the right gluteal tumour with dumbbell extension into the intermuscular plane. 


\section{Learning points}

- Lipoblastomas occur on the extremities, common in children below 3 years with a male dominance.

- A follow-up period of 2-5 years is recommended as the recurrence rate is $14-25 \%$.

- Lipoblastomatosis is a diffuse form with deeply embedded, non-capsulating, multicentric and infiltrative tumour, and wide local excision is advised.

Competing interests None.

Patient consent Obtained.
Provenance and peer review Not commissioned; externally peer reviewed.

\section{REFERENCES}

1 Akhtar T, Alladi A, Ahmed SM, et al. Giant lipoblastoma of the thigh: a rare soft tissue tumor in an infant. J Cancer Res Ther 2012;8:157-8.

2 Mognato G, Cecchetto G, Carli M, et al. Is surgical treatment of lipoblastoma always necessary? J Pediatr Surg 2000;35:1511-13.

3 Moholkar S, Sebire NJ, Roebuck DJ. Radiological-pathological correlation in lipoblastoma and lipoblastomatosis. Pediatr Radiol 2006;36:851-6.

4 Drut R, Drut RM, Toulouse JC. Hepatic hemangioendotheliomas, placental chorioangiomas, and dysmorphic kidneys in Beckwith-Wiedemann syndrome. Fetal Pediatr Path 1992:12:197-203.

5 Schneider KA. Appendix A: specific tumor types and associated syndromes. In: Schneider KA, ed. Counselling about cancer: strategies for genetic counselling. 3rd edn. Hoboken, USA.: John Wiley \& Sons, 2011:444-56.

6 Cheng $\mathrm{CH}$, Hang JF, Tsau YK, et al. Nephromegaly is a significant risk factor for renal scarring in children with first febrile urinary tract infections. I Urol 2011;186:2353-7.

Copyright 2014 BMJ Publishing Group. All rights reserved. For permission to reuse any of this content visit http://group.bmj.com/group/rights-licensing/permissions.

BMJ Case Report Fellows may re-use this article for personal use and teaching without any further permission.

Become a Fellow of BMJ Case Reports today and you can:

- Submit as many cases as you like

- Enjoy fast sympathetic peer review and rapid publication of accepted articles

- Access all the published articles

- Re-use any of the published material for personal use and teaching without further permission

For information on Institutional Fellowships contact consortiasales@bmjgroup.com

Visit casereports.bmj.com for more articles like this and to become a Fellow 